\title{
Detection of Insulin-Like Protein and Some Active Compounds in Bauhinia Variegata Linn. Leaf Ethanolic Extracts and the Effect in Reducing Blood Glucose Levels in Mice
}

\author{
Khaleel Ibrahim Rashid (PhD) \\ College of Health and Medical Technologies Foundation of Technical Education
}

\begin{abstract}
The study aims to detect the insulin-like protein and determine the active compounds in Bauhinia variegata L. leaves ethanolic extracts that help in reducing the blood glucose levels for white albino mice. The chemical detection of leaves ethanolic extract revealed the presence of tannins, terpenes, steroids, and flavonoids as active compounds. High performance liquid chromatography (HPLC) analysis method, using C18 column resulted in presence of insulin-like protein in the leaves extracts. Results showed significant reduction of blood glucose levels after 3 days of the treatment, and high reduction obtained after 6, 9, 12 days as compared with the human swine insulin used as a control. It was concluded that the crude ethanolic extracts and the partial purified insulin of B. variegata was used to examine the existence of insulin-like protein in this plant. This study is an attempt to report plant insulin that may be useful to the student in the field of pharmacology and therapeutics to develop alternative medicine to cure diabetes in human.
\end{abstract}

Key words: Bauhinia, Active compounds, HPLC analysis

\section{INTRODUCTION}

Demand for insulin will continue to grow as the incidence of diabetes increases worldwide and new delivery technologies, these new delivery technologies require a greater supply of insulin due to the increased dosing requirement of inhaled products. This reduce capital costs by $70 \%$ and cost-of-goods by more than $40 \%$ compared with current production methods, which is to achieve commercial levels of insulin expression in commercial plant system [1]. Diabetes mellitus is a systemic metabolic disease characterized by hyperglycemia, hyperlipedemia, hyperaminoacidemia, and hypoinsulinaemia it leads to decrease in both insulin secretion and insulin action. The worldwide prevalence of diabetes for all age groups was estimated to be $2.8 \%$ in 2000 and it is projected to be $5.4 \%$ in 2025 . Currently available therapies for diabetes include insulin and various oral antidiabetic agents such as sulfonylureas, biguanides, $\alpha$-glucosidase inhibitors and glinides [2]. Several species of herbal drugs have been described in the scientific and popular literature as having antidiabetic activity. Due to their perceived effectiveness, fewer side effects in clinical experience and relatively low costs, herbal drugs are prescribed $[3,4]$.

Bauhinia variegata named orchid tree, belongs to the family leguminosae, grows 10-12 meter tall with a spreading crown of briefly deciduous leaves which are $10-20 \mathrm{~cm}$ across and rounded with lobed ends and heart shaped bases. The flowers are purplish blue or even white. The genus Bauhinia were used in traditional medicine for their interesting biological activities such as, anti-diabetic, anti-inflammatory, antimicrobial, analgesic, astringent and diuretic effects [5]. Bauhinia contained many kinds of chemical constituents, primarily including flavonoids, steroids, terpenoids, tannins, lactones, glycolipids, glycosyl steroids and quinines. Five flavonoids isolated from the different parts of Bauhinia has been identified as quercetin, rutin, apigenin and apigenin 7-O-glucoside [6,3]. It was reported the detection of insulin-like antigens in a large range of species utilizing a modified ELISA plate assay and Western blotting. [7].

The presence of insulin-like molecules was recently demonstrated in the leaves of $B$. variegata where a protein was found that has a partial amino acid sequence identical to that of bovine insulin. This protein may be responsible for the lowering of blood glucose concentrations when it is injected in diabetic mice [8]. Acute toxicity studies revealed the non-toxic nature of the ethanolic extracts of $B$. variegata $\mathrm{L} . \mathrm{LD}_{50}$ studies indicate that ethanolic extract of B. variegata $\mathrm{L}$. is safer to use in animals even at a dose of $200 \mathrm{mg} / \mathrm{kg}$ of body weight [9, $10]$.

This study aims to detect the insulin-like protein and the active compounds in Bauhinia variegata leaves that help in reducing the blood glucose levels, and to achieve a source of insulin to meet the future growth of insulin demand. 


\section{MATERIALS AND METHODS}

This study was carried out in March /2012 in the college of medicine laboratories- Baghdad University and the Center of Biotechnology-Al-Nahrain University.

\section{2-1 Plant material and extraction method}

The leaves of Bauhinia variegata Linn. with white flowers were collected from Al-Nahrian University gardens in March/2012. The leaves of Bauhinia plant were washed and dried at room temperature and then reduced to coarse powder using grinding machine. $50 \mathrm{~g}$ of the powder was separately extracted with $250 \mathrm{ml}$ of ethanol, stirring for 24 hours, and then the solvent was evaporated in vacuum pressure at $40 \mathrm{C}^{\circ}$ [11].

\section{2-2 Detection of some active compounds 2-2-1 Detection of tannins}

The extract of $B$. variegata was boiled in a boiling water bath for 10 minutes, then filtered and the filtrate was treated with 5 drops of $1 \%$ lead acetate solution. The development of greenish-blue precipitate is an indicator for the presence of tannins [12].

\section{2-2-2 Detection of terpenes and steroids}

One milliliter of ethanol extract was participated in a few drops of chloroform, then 1 drop of acetate anhydride and 1 drop of concentrated sulfuric acid were added, brown precipitate appeared which representing the presence of terpene, and the appearance of dark blue color after 4-5 minutes would ensure the present of steroids [13].

\section{2-2-3 Detection of flavonoids}

Ethanol extract was partitioned with petroleum ether using Buckner funnel; the aqueous layer was mixed with the ammonia solution. The appearance of dark color is an evidence for the presence of flavonoids [13].

\section{2-2-4 High performance liquid chromatography (HPLC) analysis}

HPLC analysis was performed using the same procedure of [14]. Ethanolic and buffer extracts of $B$. variegata leaves were subjected for HPLC analysis to detect the insulin-like protein. Symmetry C18 column was used, HP-100 system (Agilent-USA), consisting of a pump with degasser, multi-wave detector (MWD). A mobile phase consisting of methanol and water (70:30), $\mathrm{pH}$ was adjusted to 2.5 using formic acid. The flow rate was $0.5 \mathrm{ml} / \mathrm{min}$. and injection volume was 15 ụl. HPLC identification was confirmed by comparison of retention indices with that of authentic standard human insulin [14].

\section{2-2-5 Experimental animals and diabetes induction}

Healthy 25 adult albino (male) mice of Swiss albino strain were obtained from the animal house of Biotechnology Research Center, Al-Nahrain University. The age of the mice was 8 weeks, and the weight was 25 gram. The animals were housed in clean plastic cages, sterilized weekly with $70 \%$ ethanol. Five mice kept in each cage with natural 14 hours light, 10 hours dark, and a controlled temperature at (24-28) $\mathrm{C}^{\circ}$. The animals were fed chow and water. The protocol was proved by [15]. The animals were fasted for 24 hours, then diabetes was induced by a single intraperitoneal (IP) injection of alloxan monohydrated dissolved in distilled water at a dose of $150 \mathrm{mg} / \mathrm{kg}$ of mice body weight in volume of $0.1 \mathrm{ml}$. The diabetic state was confirmed 72 hours after alloxan injection. Blood glucose value was reached $320 \mathrm{mg} / \mathrm{dl}$ which indicate hyperglycemia (while it was 120$140 \mathrm{mg} / \mathrm{dl}$ as standard before treatment), and there was $1 \%$ mortality in animals treated with alloxan [16].

\section{2-2-6 Experimental groups and blood sample collection}

The animals were divided into five groups (five mice per each group); the first group, control, normal mice administrated with $0.1 \mathrm{ml}$ distilled water. Second group, diabetic mice administrated with $0.1 \mathrm{ml}$ of alloxan . Third group, diabetic mice administrated with $500 \mathrm{ug} / \mathrm{kg}$ b.w. of glibenclamide. Fourth group, diabetic mice administrated with $0.1 \mathrm{ml}$ of $B$. variegata leaf ethanolic extract $(200 \mathrm{mg} / \mathrm{kg})$. For 15 days after the experiment, blood samples were collected every three days $(3,6,9,12,15)$ days, from the tail vein of the mice under the experiment, and glucose was assayed immediately using glucometer apparatus. Statistical analysis was carried out using ANOVA followed by F-test for comparison between groups. $\mathrm{P}<0.001$ was considered as a significant. 


\section{3-1 Active compounds}

\section{RESULTS AND DISCUSSION}

Table (1) revealed the presence of flavonoids, tannins, terpenes and steroids in the ethanolic and buffer extracts of B. variegata. The phytoconstituents present in the extracts may be responsible for antioxidant and antidiabetic activity in lowering of blood glucose levels. Tannins are commonly found in medicinal plants, and are non-toxic. They are soluble in water and alcohol. Tannins have pronounced physiological actions both internally and externally. When ingested they produce localized tissue reactions, such as reduce inflammation, relieve diarrhea, and reduce swelling. A major flavonoid compound of the n-butanol fraction from Bauhinia forficata leaves leads to a significant hypoglycemic effect in normal and in alloxan-induced diabetic rats [12]. Earlier reports suggest that the flavonoids, steroidal compounds and tannins are responsible for anti-diabetic activity. However, preliminary phyto-chemical study reveals the presence of, steroids, flavonoids and tannins in the alcoholic extract of Bauhinia variegata. Thus the anti-diabetic effect produced by the extract of Bauhinia variegata may be due to presence of any of these active ingredients. Flavonoids are potent antioxidants that occur naturally in foods and they can inhibit carcinogenesis in rodents [17]. Many studies are in harmony with this study results which were indicated that phenolic compounds; flavonoids protect against many types of diseases. Therefore these specific phytochemicals provide a promising area of research for future human studies and potential nutraceutical for disease prevention and treatment [18].

Table (1): Detection of some active compounds in ethanol leaves extracts of Bauhinia vareigata Linn.)

\begin{tabular}{|l|c|c|}
\hline \multicolumn{1}{|c|}{ Phytochemical compound } & Ethanol extract & Buffer extract \\
\hline Flavonoids & + & + \\
\hline Tannins & + & + \\
\hline Terpenes & + & + \\
\hline Glycosides & + & + \\
\hline Steroids & + & + \\
\hline$(+)$ present & & \\
\hline
\end{tabular}

\section{3-2 HPLC analysis}

The HPLC analysis method resulted first in a chromatogram with one clear peak for standard human insulin at retention time of 15.698 and peak area of 95.935 (Figure 1), also it was resulted in a chromatogram with three distinct peaks (Figure 2), one being the insulin-like protein peak at retention time of 15.240 and peak area of 76.552 , and the other being some compounds found in $B$. variegata ethanolic extract.

These results showed that insulin like protein was found in ethanolic and buffer extracts that prepared from the leaves of $B$. variegata plant. There were no significant differences $(\mathrm{p}<0.01)$ between the curves as determined by ANOVA with repeated measures. A new method for the economical manufacture of biopharmaceuticals from oilseeds. Plant-derived insulin accumulates to significant levels in transgenic seed and can be enzymatically treated in vitro to generate a product, the biological activity of this product in vivo and in vitro was demonstrated using an insulin tolerance test in mice and phosphorylation assay performed in a mammalian cell culture system, respectively [19].

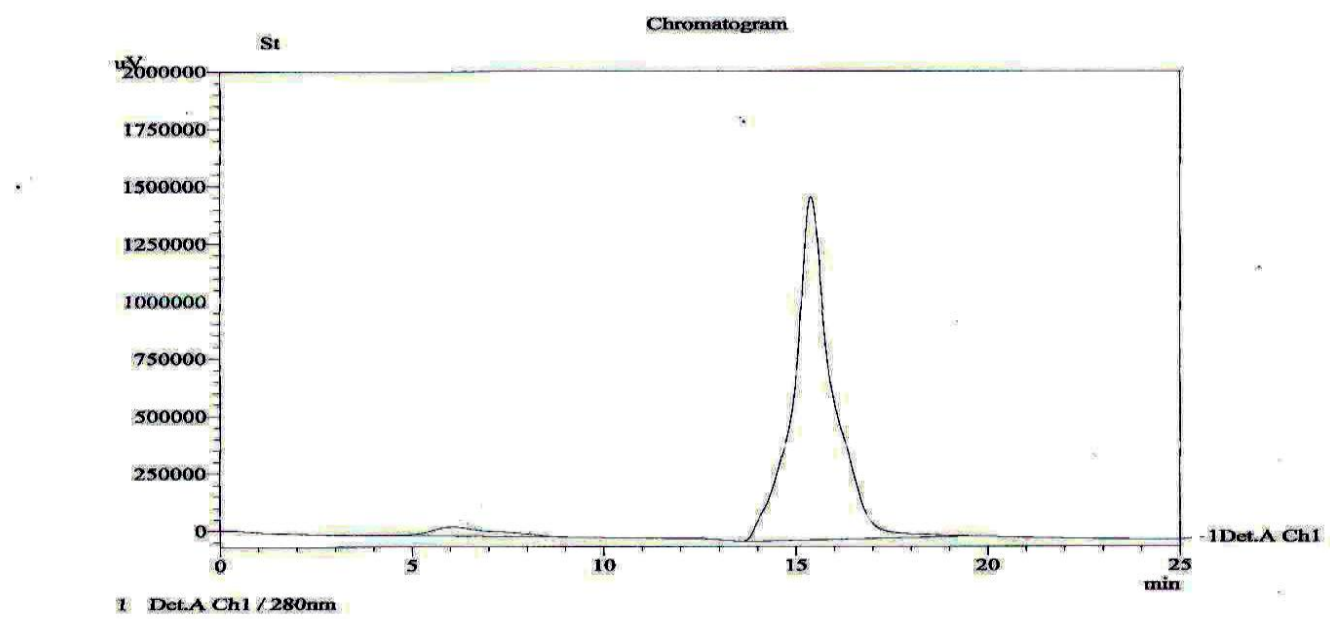

Figure (1): Sample chromatogram for insulin by HPLC techniques. Single peak represent standard human insulin 


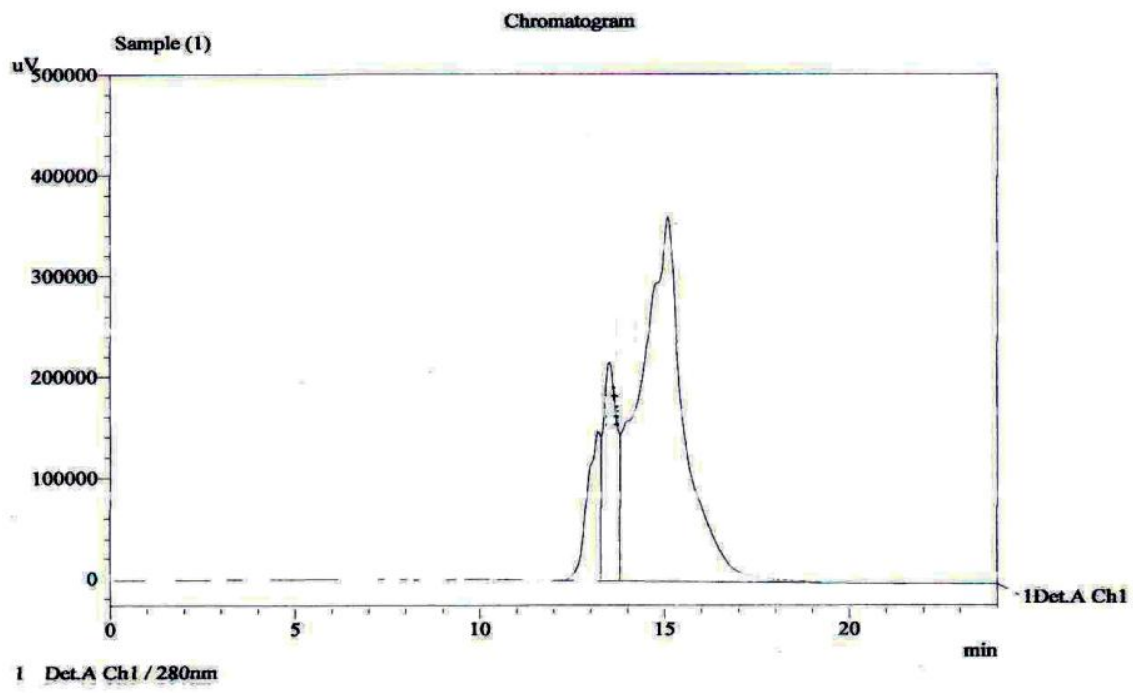

Figure (2): Sample chromatogram for insulin by HPLC techniques. Peak represents insulin in ethanolic extract of Bauhinia variegata leaves

Table 2 shows that the daily treatment with $B$. variegata ethanolic extract of $200 \mathrm{mg} / \mathrm{kg} \mathrm{b}$.w. led to a significant reduction in the blood glucose levels after 3, 6, 9 days of the treatment which recorded 194.3, 141.3, $121.6 \mathrm{mg} / \mathrm{dl}$ respectively. The effect seems to reach maximum on $12^{\text {th }}$ day of the treatment period $(119.6 \mathrm{mg} / \mathrm{dl})$ with ethanolic extract which recorded $121.0 \mathrm{mg} / \mathrm{dl}$. Significant reduction in the blood glucose level was observed as compared to the normal group $(117.6 \mathrm{mg} / \mathrm{dl})$ and diabetic group $(339.0 \mathrm{mg} / \mathrm{dl})$ after 15 days and glibenclamide treated group with gradually reduction till reached $119.3 \mathrm{mg} / \mathrm{dl}$ at the end of the test period (15 days).

These results showed that $B$. variegata leaves ethanolic extract have hyperglycemic activity as compared to the drug glibenclamide, and there were no significant differences appeared when ethanolic extract used in this experiment. The effect of the active compounds such as flavonoids that found in B. variegata leaves on glucose levels in the serum of diabetic mice caused a significant decrease in blood glucose levels in diabetic mice similar to that reported on the hypoglycemic activity of Bauhinia variegate in diabetic patients by Azevedo et al., [20]. Several published study showed that streptozotocin-diabetic rats treated with a decoction of Bauhinia forficata leaves presented a significant reduction in serum and urinary glucose as compared to streptozotocindiabetic controls [21].

Table (2): Effect of Bauhinia variegata leaves ethanolic extract on reducing blood glucose levels of white albino mice after different treatments

\begin{tabular}{|c|c|c|c|c|c|c|c|}
\hline \multirow{2}{*}{$\begin{array}{c}\text { Group/treat. } \\
(n=5)\end{array}$} & \multirow[b]{2}{*}{ Dose } & \multicolumn{6}{|c|}{ Blood glucose level (mg/dl) average } \\
\hline & & 0 Day & 3 days & 6 days & 9 days & 12 days & 15 days \\
\hline $\begin{array}{l}\text { Normal mice } \\
\text { (control) }\end{array}$ & $\begin{array}{c}0.1 \mathrm{ml} \\
\text { distilled water }\end{array}$ & 118.6 & 120.0 & 116.6 & 119.3 & 118.6 & 117.6 \\
\hline $\begin{array}{l}\text { Induced diabetic } \\
\text { mice with alloxan } \\
\text { (control) }\end{array}$ & $\begin{array}{c}0.1 \mathrm{ml} \\
(150 \mathrm{mg} / \mathrm{kg})\end{array}$ & 330.3 & 335.3 & 329.0 & 336.3 & 339.0 & 338.3 \\
\hline $\begin{array}{l}\text { Diabetic mice } \\
\text { (glibenclamide) }\end{array}$ & $\begin{array}{c}0.1 \mathrm{ml} \\
(500 \mathrm{ug} / \mathrm{kg})\end{array}$ & 326.0 & 202.0 & 132.3 & 121.6 & 121.3 & 119.3 \\
\hline $\begin{array}{l}\text { Diabetic mice } \\
\text { (ethanolic extract) }\end{array}$ & $\begin{array}{c}0.1 \mathrm{ml} \\
(200 \mathrm{mg} / \mathrm{kg})\end{array}$ & 320.0 & 194.3 & 141.3 & 121.6 & 119.6 & 121.0 \\
\hline F-test & & 3159.5 & 1325.7 & 1498.9 & 8526.3 & 10288.8 & 14390.5 \\
\hline P-value & & 0.0001 & 0.0001 & 0.0001 & 0.0001 & 0.0001 & 0.0001 \\
\hline
\end{tabular}


Insulin in plant exhibit metabolic functions as those of animal insulin by promoting several metabolic activities through glucose transportation into the cell and by phosphorylating proteins regulating carbohydrate metabolism as evidenced by many studies. However, isolated Insulin-like protein is found to have synergistic effect in reducing blood glucose level in experimental animals and most of the insulin-like proptein of different plant species shows peptide sequence homology with insulin. Plant insulin ingested together with protease inhibitors is protected from hydrolysis in the digestive tract, crosses the intestinal barrier and promotes lowering of blood glucose levels [22]. The leaves of plants of many Bauhinia species are used in antidiabetic treatments by many populations of the world. The presence of insulin-like molecules was recently demonstrated in the leaves of $B$. variegata where a protein was found that has a partial amino acid sequence identical to that of bovine insulin [23].

It was concluded that the crude ethanolic extract of $B$. variegate was used to examine the existence of insulin-like protein in this plant using HPLC techniques. Treating diabetes mellitus with plant derived compounds which are accessible and do not require laborious pharmaceutical synthesis seems highly attractive. An attempt has been made to report that plant insulin-like protein and the active compound in this plant may be useful to the scientists and researchers working in the field of pharmacology and therapeutics to develop an alternative medicine to cure diabetes diseases in humans.

\section{ACKNOWLEDGEMENT}

The authors are thankful to Dr. Abdujassim Aljibouri. The manager of Biotechnology Center-AlNahrain University, Dr.Shayma J. Ahmed and Dr. Malak A. Taha, College of Medicine - Baghdad University for providing all the facilities and support to carry out the practical part of the research.

\section{REFERENCES}

[1.] Pereira, R. C.; Oliveira, M. TR. and Lemos, G. CS. (2004). Plantas utilizadas como medicinais no municipio de Campos de Goylacazes - RJ. Rev. Brsa. Farmacogn., 14(1); 37-40.

[2.] Thiruvenka, R. and Jayakar, B. (2010). Anti-Hyperglycemic and Anti-Hyperlipidaemic activities of Bauhinia. Der Pharmacia Lettre, 2(5): 330-334

[3.] Rajani, G. P.,and Purnima, A. (2009). In vitro antioxidant and antihyperlipidemic activity of Bauhinia variegata Linn. Indian J. Pharmacol.,;41(5)227-32.

[4.] Ghaisas, M. M.; Shaikh, S. A.,and Deshpande, A. D. (2009). Evaluation of the immunomodulatory activity of ethanolic extract of the stem bark of Bauhinia variegata Linn. Int. J. Green Pharm., 3:70-4.

[5.] Chu, W. L. (2005). SemBioSys Reports Positive Preclinical Results of Plant Produced Insulin. In the Plant Biotechnology Journal.

[6.] Silva, K. L. and Cechine-Filho, V. (2002). Plantas do genero Bauhinia: Composicao quimica epotencial farmacologico. Quim. Nova. 25: 121-125.

[7.] Barbosa-Filho, JM.; Vasconcelos, THC.; Alencar, AA.; Batista, LM.; Oliveira, RAG.; Guedes, DN.; Falcao, HS.; Moura, MD.; Diniz, MFFM. and Modesto-Filho, J. (2005). plants and their active constituents from south, Central, and North America with hypoglycemic activity. Rev. Bras. Farmacogn, 15: 392-413.

[8.] Azevedo, C. R. (2003). Caracterização parcial de insulina de folhas de Bauhinia variegata. [Master's thesis]. Campos dos Goytacazes: Centro de Biociências e Biotecnologia, Universidade Estadual do Norte Fluminense.

[9.] Feldman, J. M. (1988). In Diabetes Mellitus, 9th ed. Indianapolis, Eli Lilly \& co., pp: 28-42.

[10.] Strojek, K. (2003). Features of macrovascular complications in type 2 diabetic patients. Acta Diabetologica, 40, 334-337.

[11.] Akueshi, C. O.; Kadiri, C. O.; Akueshi, E. U.; Agina, S. E. and Gurukwem, B. (2001). Antimicrobial potential of Hyptis sauvedens Poit (Lamiaceae), Nigeria. J. Bot., 15: 37-41.

[12.] Evans, W. C. (1989). Pharmacognosy 13th (Eds) Balliere Tindal, London, 419-420.

[13.] Harborne, J. B. (1984). Phytochemical methods. A guide to Modern Technique of Plant Analysis, Chapman Hall, London.

[14.] Almela, L.: Sanches-Muno, B.; Frenandez-Lopez, J.; RRoca, M. and Rabe, V. (2006). Liquid Chromatographic-Mass Spectrometric analysis of phenolic and free radical scavenging activity of rosemary extract from different raw materials. J. Chromatog., 1120(1-2):22-229.

[15.] Institutional Animal Ethical Committee JKKMMRF/CP/PhD (2008).

[16.] Mukhtar, H. M., Ansari, S. H., Ali, M., Naved, T. and Bhat, Z. A. (2004). J. Nat. Remed. 4 (2): 150-154.

[17.] Dhanabal, S. P., Kokate, C. K., Ramanathan, M., Elango, K., Kumar, E. P. and Subburaj, T. (2004). Indian Drugs. 41(11): 690695.

[18.] National Center for Complementary and Alternative Medicine. (2012). Antioxidant Supplements for Health: An Introduction.

[19.] Cory, L. N., Joseph, G.. B., Elizabeth, W. M., Richard, G. K., Goren, H. J., Nancy, A. M. and Maurice M. M. (2005). Transgenic expression and recovery of biologically active recombinant human insulin from Arabidopsis thaliana seeds. Plant Biotechnology Journal, Blackwell Publishing Ltd.3.

[20.] Azevedo C. R., Maciel1, F. M., Silval, L. B., Ferreira1, A. T. S., Cunha, M. and Machado, O. L. T. (2006). Isolation and intracellular localization of insulin-like proteins from leaves of Bauhinia variegata. Braz J Med Biol Res. 39(11):1435-1444.

[21.] Silva, F. R., Szpoganicz, B., Pizzolatti, M. G., Willrich, M. A. and de Sousa, E. (2002). Acute effect of Bauhinia forficata on serum glucose levels in normal and alloxan-induced diabetic rats. $J$ Ethnopharmacol. 83: 33-37.

[22.] Chiou, T. J. and Bush, D. R. (1996). Molecular cloning, immunochemical localization to the vacuole, and expression in transgenic yeast and tobacco of a putative sugar transporter from sugar beet. Plant Physiol 110: 511-520.

[23.] Pepato, M. T., Keller, E. H., Baviera, A. M., Kettelhut, I. C., Vendramini, R. C. and Brunetti, I. L. (2002). Anti-diabetic activity of Bauhinia forficata decoction in streptozotocin-diabetic rats. J. Ethnopharmacol. 81: 191-197. 